Venter, $\mathrm{R}^{1}$
University of the Free State

\title{
Trinity and beauty: The theological contribution of Jonathan Edwards ${ }^{2}$
}

\begin{abstract}
The article explores the relationship between the trinitarian confession of God and beauty. Special attention is paid to Jonathan Edwards, the eighteenth-century preacher and thinker, who in an exceptional manner viewed God in terms of beauty. The discussion is located in the context of a vigorous international Edwardsian scholarship on metaphysics, the nature of God and aesthetics. The article points out that beauty, according to Edwards, is primarily relational. The article aims at contributing to two neglected scholarly areas - the treatment of the doctrine of God in aesthetic terms, and the study of Jonathan Edwards in a South African context. Areas for further reflection are also identified. The article intimates that a discussion about trinity and beauty may have social ramifications.
\end{abstract}

\section{INTRODUCTION}

What name could we assign to the present? What description would best suit our social condition? Examining the challenges of our time - violence, corruption, alienation and cynicism - one may rightly suggest ugliness as an appropriate candidate. Our time has become devoid of beauty. Referring to the political past, De Gruchy (2008:1) claims "Apartheid was not only unjust, but also ugly ...", and continues to assert that there is a close relationship between ugliness and oppression, and between beauty and redemption. What comes into focus is nothing but the claim that beauty and social transformation are inextricably linked. One may, however, probe deeper, and raise the question of the very eclipse of beauty as a social descriptor. Why has our time become one of growing ugliness? Perhaps the loss of beauty and the loss of transcendence go together (cf. Moore 2004:155ff) or, to put it more positively, the hope for a retrieval of beauty as quality of social life should begin with a restoration of respect for God as public reality.

One of the urgent tasks of constructive theology is to establish reflectively the relationship between the Christian understanding of God, that is the trinity, and social beauty. Interestingly, both these fields have become separate areas of much scholarly interest. The second half of the twentieth century has experienced theologically the so-called Trinitarian Renaissance (cf. Kärkkäinen 2007), ${ }^{3}$ and an enthusiasm for the Arts and Aesthetics (cf. De Gruchy 2005 \& Dyrness 2007). ${ }^{4}$ Despite these encouraging signs, the neglect of both the trinity and beauty in creative theological discourse should not be easily forgotten. Especially in the Reformed Tradition the question should be addressed as to what extent the trinity and beauty have received the

1 Head: Department Dogmatology. University of the Free State. Bloemfotnein

2 Revised version of paper presented at the occasion of the inauguration of the Jonathan Edwards Center Africa. UFS. March 9, 2010.

3 A large number of theologians have continued the groundbreaking work of Barth and Rahner; e.g.

Pannenberg, Moltmann, Jenson, Gunton, LaCugna, Boff and Zizioulas.

4 The foundational work by Von Balthasar is most important. More recently the names of e.g. Begbie, Hart, Dyrness, Farley, Sherry, Viladesau, and García-Rivera can be mentioned. 
sustained attention they deserve. Barth (1957:651) has lamented the fact that the Reformation and Protestant Orthodoxy have "completely ignored" the question of beauty. Recently two Dutch theologians (Van den Brink \& Van Erp 2009:89) raised the question as to whether Dutch theology, which has deeply influenced theology in South Africa, is "missing the boat" concerning the new interest in the trinity.

The basic emphasis of this article is that theology and Reformed theology, in particular, may do well to attend to a voice not particularly known in South Africa - that of Jonathan Edwards (1703-1758). The theological work of this eighteenth-century New England Puritan preacher is surprisingly of particular relevance to twenty-first-century theology. One of his wide-ranging intellectual achievements deserves special attention: his consistent thinking about God in terms of beauty. It is an open question whether any one in the Reformed tradition can match his profound intuition that the biblical God is essentially glorious, excellent and beautiful. The aim of this article is to draw attention to his remarkable theological contribution.

\section{EDWARDS IN CONTEXT}

The question arises about an adequate entry to the views of Edwards on God and beauty. Several perspectives should be considered in this instance: the nature of his literary output, the particular historical and intellectual background of his life, and current Edwardsian scholarship. Studies on his metaphysics, his view on God and the trinity, and his aesthetics should be mentioned, in particular, and are relevant for this brief article; notes will be given as background.

The occasional nature of his literary output, which is unlike the typical systematic treatment of trinitarian discourses in for instance the twentieth century, must be mentioned. Once this is coupled with the creative and adventurous nature of his thought, one can understand the divergent interpretations of his thought. In this regard the Jonathan Edwards Centre at Yale University must draw attention to the seminal work. ${ }^{5}$ The primary work by Edwards is available online with critical introductions. The work of Minkema (see e.g. 2004) is important to keep abreast of the burgeoning scholarship on various aspects of Edwards's work.

The research by Sang Hyun Lee is crucial to understand Edwards's contribution to a new metaphysics (see 1999 \& WJE 21:5). Reality should not be understood in terms of self-contained substances, but rather as essentially "dispositional", intrinsically dynamic and relational. Being is inherently disposed towards more activities and relationships, or to "further increases of being" (Lee 1999:447). According to Lee, this dispositional ontology undergirds Edwards's understanding of God and the world (1999:446). The implication of this for an understanding of God is obvious: God is dynamic, relational and communicative. In recent years scholars such as Crisp (e.g. 2010) have challenged Lee's influential work. Crisp questions whether Edwards did effectively replace the notion of substance with that of disposition. According to him, Edwards was an occasionalist, who stressed continuous creation and God as sole causative agent. This fascinating debate may eventually have interesting consequences for studies on Edwards.

The debate about metaphysics has ramifications for Edwards's understanding of the divine nature. At stake is the question whether his doctrine of God amounts to an innovation in Reformed Theology. Crisp (cf. 2009) has addressed this at length, and emphasised that Edwards viewed himself as in continuation with the views of Reformed orthodox theologians such as Turretin and Van Mastricht. The specific issue is whether Edwards could, on the one hand, maintain allegiance to an actus purus account of the divine nature (that is, there is no distinction between act and being) and the corollary of divine simplicity, and make provision for the notion of disposition, on the other. Does this amount to intellectual inconsistency, or a reconceptualisation of theism as

5 See http://edwards.yale.edu

186 Deel 51 Nommer 3 \& 4 September en Desember 2010 
suggested by Lee? Crisp argues that Edwards's claim that God is essentially disposed to create is "an innovation of a sort" and rather "a development of a pure act account of the divine nature, rather than a departure from it" (2009:196). Interestingly, these questions have re-opened the conversation on the doctrines of the trinity and the divine attributes, such as simplicity.

Pauw has rendered a particular service to scholarship on Edwards's trinitarianism with her work "The Supreme Harmony of all" (2002) and highlights his ability to negotiate two divergent approaches to trinitarian construal - the so-called psychological and social models. Edwards's ambidexterity is clearly apparent in his balancing act of employing analogies of both the human mind and society to picture God as simultaneously one and relational. In this "cobbled trinitarianism" with its various language games (2002:189), each avenue enabled Edwards to address different aspects of the history of redemption; each has its distinctive role to play. Although the freedom in trinitarian adventure, as reflected in his notebooks, the so-called Miscellanies, does not always match similar attention in his sermons and later treatises, his trinitarianism "ran like a subterranean river throughout his career" (2002:3). Not only did he assert the basic orthodox trinitarian confession, he also interpreted it to meet the challenges of his time. At stake was the ambitious project of offering an alternative interpretation of reality as such. The charges against the very orthodoxy of his trinitarian views could be viewed against this background (cf. Weber 2001). The debate about the character and background of Edwards's trinitarian theology will probably continue. Recently Studebaker (2004) questioned Pauw's proposal about the employment of both models; he contends that Edwards consistently uses the Augustinian mutual love model (2004:482). In the end hermeneutical differences of basic texts will remain, and the in/tolerance for ambivalence and conflict in Edwards's thought by interpreters will be decisive (cf. also Pauw 2004:488).

Considering the association of Edwards with Puritanism and an extreme Calvinist position, one is surprised by the attention to beauty in his work (Thiessen 2004:157). Farley (2001:43) even claims that in the literary output of Edwards "beauty is more central and more pervasive than in any other text in the history of Christian theology". Scholarship has been well served by in-depth studies by, among others, Delatrre (1968/2006) and Mitchell (2003), and this article will also make extensive use of this research. Edwards's exploration of beauty should be situated in the mid-eighteenth century, which experienced a crucial shift in the history of aesthetics from beauty as being to beauty as human self-transcendence. According to Farley (2001:32f), a relocation of beauty has taken place at this time: from an external property to a human sensibility. This subjectivist move to human experience has set in motion the eventual relativization of beauty. Edwards participated in this turn, but with a critical difference: primary beauty is to be informed by God. He succeeded in combining a subjective and objective notion of beauty (Farley 2001:47); beauty is both being and sensibility.

\section{THE VISION OF BEAUTY}

The creative exploration of trinitarian resources is not the particular feat of Edwards's theology, but the qualification - beauty - that he introduced to the great mystery at the heart of the Christian faith. To articulate an essentially orthodox Calvinist vision of reality along aesthetic lines remains a singular achievement until the present time. Beauty is the first theological and ontological principle, that is, the distinguishing mark of being as such and of God's perfection.

a. We find in his work a variety of words that belong to the semantic field of beauty: Excellency, glory, symmetry, proportion, harmony, consent, union, love and holiness. He further distinguishes between simple/complex, and secondary/primary beauty. Primary beauty is found where beings 
are capable of choice and love; the well-known definition found in his work is consent to being:

"This is an universal definition of excellency: The consent of being to being, or being's consent to entity. The more the consent is, and the more extensive, the greater is the excellency" (WJE Online vol 6:336).

b. At the centre of Edwards's aesthetic vision is God, the beginning and end of beauty:

"Because God is not only infinitely greater and more excellent than all other being[s]; but he is the head of the universal system of existence; the foundation and fountain of all being and all beauty; from whom all is perfectly derived, and on whom all is most absolutely and perfectly dependent; of whom, and through whom, and to whom is all being and all perfection; and whose being and beauty is as it were the sum and comprehension of all existence and excellence: much more than the sun is the fountain and summary comprehension of all the light and brightness of the day" (WJE Online vol 8:551).

This exclusive theocentric approach to beauty requires careful theological attention. This insight should be emphasised: being and beauty are one in God. The very divinity of God should be understood in terms of beauty:

"... the true notion of divinity: God is God, and distinguished from all other beings, and exalted above 'em, chiefly by his divine beauty, which is infinitely diverse from all other beauty" (WJE Online vol 2:298).

Beauty gives an insight into the mystery of God. The traditional divine perfections must be viewed in this light. For Edwards there is a close connection between beauty and holiness. Holiness is the sum of the moral perfections -

"The true beauty and loveliness of all intelligent beings does primarily and most essentially consist in their moral excellency or holiness ... The holiness of an intelligent creature, is the beauty of all his natural perfections. And so it is in God, according to our way of conceiving of the Divine Being: holiness is in a peculiar manner the beauty of the divine nature" (WJE Online vol 2:257).

For Edwards beauty and the divine glory are virtually identical; glory is a more comprehensive term than holiness and includes all the good in God; beauty conveys what is peculiar to this glory (cf. Delattre 1968:136f).

The crucial intellectual contribution by Edwards in this instance should be appreciated. Delattre (1968:146) captures this aptly: "the divine majesty was for him a lovely rather than an awful or awesome majesty". Marsden in his authoritative biography (2003:41ff) refers to the "Copernican revolution" which Edwards experienced at a relatively early age, a "whole new perspective" on God's character and relationship to the world; He is "ineffably good, beautiful, and loving" (2003:43).

According to Edwards, beauty is inherently relational; simplicity cannot qualify for being beautiful; beauty requires complexity:

"Again, we have shown that one alone cannot be excellent, inasmuch as, in such case, there can be no consent. Therefore, if God is excellent, there must be a plurality in God; otherwise, there can be no consent in him" (WJE vol 13:284).

The world of Edwards was one of personal relationships (Marsden 2003:503f). The central concern of this article - trinity and beauty - crystallises with this. The perfection, the excellency, the beauty of God is found in the loving and harmonious relations of consent in the triune life 
(cf. Pauw 2002:80-83). Beauty is a divine person in relation (Mitchell 2003:12). Only where there is sociality, complex harmony and consent does beauty emerge:

"His infinite beauty is his infinite mutual love of himself" (WJE Online vol 6: 363).

With his major study on beauty in the thought of Edwards, Delattre (1968) highlights the special role of the Holy Spirit. The Holy Spirit is God's eternal consent to being; the Holy Spirit is God's intra-trinitarian love. The typical Edwardsian way of formulating the trinitarian confession was to refer to "God, and his idea, and his love or delight" (WJE vol 13:368). The Holy Spirit ís the beauty of God:

"It was more especially the Holy Spirit's work to bring the world to its beauty and perfection out of the chaos, for the beauty of the world is a communication of God's beauty. The Holy Spirit is the harmony and excellency and beauty of the Deity, therefore 'twas his work to communicate beauty and harmony to the world, and so we read that it was he that moved upon the face of the waters [Genesis 1:2]" (WJE vol 13:293).

In the well-known sermon "The excellency of Christ" on Revelation 5:5-6 (1734) the beauty of Christ is understood as the uniting of the diverse qualities of divine and human. The more disparate the entities are that are conjoined, the greater the beauty - "Such a conjunction of such infinite highness, and low condescension" (WJE Online vol 19: 566).

c. The term glory has two references: the excellency, beauty of the triune life, but also the overflow of this life to creation (cf. Mitchell 2007:39f). Creation is the overflow of divine beauty. This dynamic and dispositional view allows a novel understanding of creation; God has not created ex nihilo, and He has not remained unaffected. He created out of the fullness of his divine beauty, and this enlarged his own triune life (WJE Online vol 8:461f)! In this way it is possible to assert that beauty is the very structure of being.

d. In Edwards beauty has both an objective and subjective dimension. Beauty as trinitarian perfection and beauty as gift to creation should be experienced. The pressing issue of his day - the nature of genuine religious experience - received light from this perspective. Mitchell (2007) emphasised that beauty is the structure of religious experience. The sense of the heart is "an experience of God's beauty that is manifested in beautiful affections" (2007:42 n26). The life of the Christian is a life of beauty experienced and embodied. Primary beauty becomes the foundation of all virtue and ethics. True virtue is nothing but "benevolence to being" (WJE Online vol 8:571).

\section{SUGGESTIONS FOR FURTHER REFLECTION}

The advice by Pauw (1999:459) that "Edwards's spirit of theological adventure is one Reformed Christians would do well to imitate" is worth heeding. The basic compass direction to engage creatively with the intellectual horizon, to concentrate on the trinitarian nature of God, and to explore the mystery of God not kyriologically, i.e. in terms of power, but aesthetically, is most commendable. Time and again a student of Edwards is surprised by his relevance for our day. In many instances his fundamental intuition, e.g. to think relationally, to understand the perfection(s) of God trinitarianly, and to retrieve beauty as theological optic, anticipated central concerns of current theological discourse.

Briefly four areas for further reflection - in light of Edwards's views on beauty and trinity can be identified: 
The very connection of God and beauty is a neglected theme in theology and Edwards's achievement can hardly be overemphasised. A comparison with Barth, the one Reformed theologian who has given space to beauty, is interesting. Barth discusses beauty in the context of the glory of God, the sum of all divine perfections. Beauty is the form, the manner of God's glory $(1957: 650,654)$. Insofar as the glory is effective (1957:653), it is beautiful: God's glory "gives pleasure, creates desire and rewards with enjoyment" (1957:651). Despite these bold assertions, Barth remains cautious and registers qualifications: "We speak of God's beauty only in explanation of his glory. It is, therefore, a subordinate and auxiliary idea ... (1957:653). He stresses that beauty has no independent significance in the Bible, and resists bringing the knowledge of God under the denominator of the idea of the beautiful (1957:652f). His preferred expression is: "God is 'also' beautiful" (1957:655). Nothingstanding these provisos, Barth does make profound statements such as God is the "basis and standard of everything that is beautiful" (1957:656). He explicitly connects beauty and trinity. The 'content' of the divine being creates the particular 'form' of the divine being: "the triunity of God is the secret of his beauty" (1957:661). These very ideas warrant further reflection, and should be valued as constructive advances in theological knowledge. In what sense the trinity and beauty are to be viewed together should be further explored.

The vision of the Christian God as beautifying should inform the orientation of Christian ethics. Delattre (2003) has made a persuasive plea for this. The Christian ethos should be a participation in the divine life. A life of true virtue is a beautifying life (2003:287). Beauty should be a guide for individual, social and ecological ethics. Christian virtuous life has to be in all dimensions a beautifying practice. Consent to being may imply the benevolence to life in all its dimensions. Beauty, trinity and social flourishing belong together. The genius of Edwards, the 'moralization of beauty' (Farley 2001:46) is to be maintained: primary beauty is a moral disposition. God's holiness is what defines his beauty. In benevolence primary beauty and the moral coincide. Such a vision for an 'aesthetic existence' in the South African context has been exceptionally intimated by Barrett (cf. 2004); the key task is to seek beauty in the life of the nation as such. This very line of thinking is worth pursuing further.

Highlighting beauty as the distinguishing perfection of God may be a most effective apologetical approach. Argumentation, evidence, logic and reason do not have an impressive record in a secular age. In light of the work by Edwards, Wooddell (2007) rightly raises the question whether there is not space for an alternative - apologetics informed by beauty. Beauty is directly compelling; it is immediately recognised and attractive as such. Influential studies have shown that the loss of faith in the Christian God is often occasioned by tyrannical and oppressive portrayals of the divine, images not informed by his glorious trinitarian nature. Vanhoozer (2006) has observed this with clarity. According to him, apologetics would be better served by arguments that focus on God's identity (2006:42). He pleads for "an enlarged concept of argument" that "render[s] Christian truth artistically as well as argumentatively" (2006:38).

Edwards's explicit connection of beauty and Spirit opens a number of avenues in need of further exploration, in particular for spirituality and artistic expression. The Cinderella status of the Holy Spirit in theology has had far-reaching negative implications for the church. Retrieving an appreciation for the mutual relationship between aesthetics and pneumatology, as for example advocated by Sherry (2007) in light of Edwards, may result in a fresh appreciation of the arts for Christian life and spirituality. From the earliest human civilisation, as can be found in cave paintings, one can detect an intrinsic spirituality in the experience of beauty. Beauty points to its transcendence. A theological aesthetics recognises that God's glory is the transcendent referent to the experiences of beauty. García-Rivera (2005:360) is arguably correct when stating, "aesthetics is about to become, once again, a companion to spirituality." 
The ugliness of our time is not inevitable. The Christian faith testifies to a God who is beautiful and beautifying. Edwards's intellectual labour continues to remind us about this. We are fortunate that our theological explorations, ethical practices, apologetical efforts, spiritual journeys and contextual engagements may be beautiful, because the triune God is excellent.

\section{BIBLIOGRAPHY}

Barrett, P 2004. The quest for a uniting vision in South Africa: A question of beauty. Journal of Theology for Southern Africa 119:15-31.

Barth, K 1957. Church Dogmatics 2/1. Edinburgh: T \& T Clark.

Crisp, O D 2010. Jonathan Edwards's ontology: A critique of Sang Hyun Lee's dispositional account of Edwardsian metaphysics. Religious Studies 46:1-20.

--- 2009. Jonathan Edwards on the divine nature. Journal of Reformed Theology 3:175-201.

De Gruchy, J W 2008. Christianity, art and transformation: Theological aesthetics in the struggle for justice. Cambridge: Cambridge University Press.

--- 2005. Theology and the arts, in Ford, D F \& Muers, R (eds), The modern theologians, $3^{\text {rd }}$ ed, 706-718. Oxford: Blackwell.

Delattre, R A 2003. Aesthetics and ethics: Jonathan Edwards and the recovery of aesthetics for religious ethics. Journal of Religious Ethics 31(2):277-297.

--- 1968 (2006). Beauty and sensibility in the thought of Jonathan Edwards. Eugene, OR: Wipf \& Stock.

Dyrness, W A 2007. The arts, in Webster, J, Tanner, K \& Torrance, I (eds), The Oxford handbook of systematic theology, 561-579. Oxford: Oxford University Press.

Edwards, J (2008)

--- Religious Affections (WJE Online Vol. 2), Ed. Paul Ramsey. New Haven: Jonathan Edwards Center.

--- Scientific and Philosophical Writings (WJE Online Vol. 6), Ed. Wallace E. Anderson. New Haven: Jonathan Edwards Center.

--- Ethical Writings (WJE Online Vol. 8), Ed. Paul Ramsey. New Haven: Jonathan Edwards Center.

--- The "Miscellanies": (Entry Nos. a-z, aa-zz, 1-500) (WJE Online Vol. 13), Ed. Harry S. Stout. New Haven: Jonathan Edwards Center.

--- Sermons and Discourses, 1734-1738 (WJE Online Vol. 19), Ed. M. X. Lesser. New Haven: Jonathan Edwards Center.

Farley, E 2001. Faith and beauty: A theological aesthetics. Aldershot: Ashgate.

García-Rivera, A 2005. Aesthetics, in Holder, A (ed), The Blackwell companion to christian spirituality, 345362. Oxford: Blackwell.

Kärkkäinen, V-M 2007. The trinity: Global perspectives. Louisville: Westminster John Knox.

Lee, S H (2008) Editorial - introduction to the doctrine of the trinity, in WJE Online vol 21, pp.2-38.New Haven: Yale Univ Press.

--- 1999. Jonathan Edwards's dispositional conception of the trinity: A resource for contemporary reformed theology, in Willis, D \& Welker, M (eds), Towards the future of reformed theology, 444-455. Grand Rapids: WB Eerdmans.

Marsden, G M 2003. Jonathan Edwards: A life. New Haven: Yale University Press.

Minkema, K P 2004. Jonathan Edwards in the twentieth century. Journal of the Evangelical Theological Society 47(4):659-687.

Mitchell, LJ 2007. The theological aesthetics of Jonathan Edwards. Theology Today 64:36-46.

--- 2003. Jonathan Edwards on the experience of beauty. Studies in Reformed theology and history no 9. Princeton: Princeton Theological Seminary.

Moore, T M 2004. The hope of beauty in an age of ugliness and death. Theology Today 61:155-72.

Pauw, A P 2004. Response. Scottish Journal of Theology 57(4):486-489.

--- 2002. The supreme harmony of all: The trinitarian theology of Jonathan Edwards. Grand Rapids: W B Eerdmans.

--- 1999. The future of reformed theology: Some lessons from Jonathan Edwards, in Willis, D \& Welker, M (eds), Towards the future of reformed theology, 456-469. Grand Rapids: W B Eerdmans.

Sherry, P 2007. The beauty of God the Holy Spirit. Theology Today 64:5-13.

Studebaker, S M 2004. Supreme harmony or supreme disharmony? An analysis of Amy Plantinga 
Pauw's 'The supreme harmony of all': The trinitarian theology of Jonathan Edwards. Scottish Journal of Theology 57(4):479-485.

Thiessen, G E 2004. Theological aesthetics: A reader. London: SCM.

Van den Brink, G \& Van Erp, S 2009. Ignoring God triune? The doctrine of the trinity in Dutch theology. International Journal of Systematic Theology 11(1):73-90.

Vanhoozer, KJ 2006. Theology and apologetics, in Campbell-Jack, C \& McGrath, G J (eds). New Dictionary of Christian Apologetics, 35-43. Leicester: Inter-Varsity Press.

Weber, R M 2001. The trinitarian theology of Jonathan Edwards: An investigation of charges against its orthodoxy. Journal of the Evangelical Theological Society 44(2):297-318.

Wooddell, J D 2007. Jonathan Edwards, beauty, and apologetics. Criswell Theological Review 5(1):81-95.

\section{KEY WORDS}

Jonathan Edwards

Trinity

Beauty

Aesthetics

\section{TREFWOORDE}

Jonathan Edwards

Triniteit

Skoonheid

Estetika

Prof Rian Venter

Fakulteit Teologie

Universiteit van die Vrystaat

Posbus 339

BLOEMFONTEIN. 9300

Tel: (051) 4512254

Sel: 0722095956

E-pos: rianventer@mweb.co.za 